University for Business and Technology in Kosovo

UBT Knowledge Center

UBT International Conference

2014 UBT International Conference

Nov 8th, 12:45 PM - 1:00 PM

\title{
Compensation Strategy for the New Economy Age
}

\author{
Besnik Skenderi \\ University for Business and Technology, besnik_skenderi@yahoo.com \\ Diamanta Skenderi \\ University for Business and Technology, diamanta_skenderi@yahoo.com
}

Follow this and additional works at: https://knowledgecenter.ubt-uni.net/conference

Part of the Business Commons

\section{Recommended Citation}

Skenderi, Besnik and Skenderi, Diamanta, "Compensation Strategy for the New Economy Age" (2014). UBT International Conference. 49.

https://knowledgecenter.ubt-uni.net/conference/2014/all-events/49

This Event is brought to you for free and open access by the Publication and Journals at UBT Knowledge Center. It has been accepted for inclusion in UBT International Conference by an authorized administrator of UBT Knowledge Center. For more information, please contact knowledge.center@ubt-uni.net. 


\title{
Compensation Strategy for the New Economy Age
}

\author{
Besnik Skenderi ${ }^{1}$, Diamanta Skenderi ${ }^{2}$ \\ ${ }^{1,2}$ University for Business and Technology \\ Tax Administration of Kosovo \\ besnik_skenderi@yahoo.com ${ }^{1}$, diamanta_skenderi@yahoo.com ${ }^{2}$
}

\begin{abstract}
This paper is about motivation and compensation philosophy, since 15th century businesses are using the same performance measuring system and reward schemes. Performance is equal with sum of staff motivation and their ability to perform. Some companies are using bonus payments and penalties, depending on success or on failure regarding performance of their staff. Regarding motivation literature is proving different theories, but the issue is that employees nowadays are more informed and have greater expectation from companies regarding compensation.
\end{abstract}

Keywords: Motivation, Compensation, Stock Options

\section{Motivation and Measurement}

Business literature and managers in developed countries like US, Germany and Japan are struggling with concept of managing for value. Since 15th century, businesses are using the same performance measuring system and reward schemes. Because of flooding of diversified talents in the New Economy, the "Old Economy" faces with difficulties in order to deal with crucial strategic transition. Staff performance is equal with sum of motivation and ability to perform, but the challenge remains with measurement of performance. Stewart (2000) discusses statement "What gets measured gets managed" (p.1), however the question, which arises from this statement, is do managers measure what they should. Stewart (2002) concludes that traditional accounting system ignores shareholder expectations regarding return on invested capital and everything, which is beyond, value of zero is considered as good performance. In this way, managers are decreasing the value of companies even that in their balance sheets it looks like they are performing well.

At the company where author is employed, PTK (Post and Telecom of Kosovo), business strategy is used to create business plans for business units. Business plans are translated into objectives for directors and then directors write objectives for their subordinates. This routine is followed top down from managers to all PTK staff members; however there are many cases where objectives are set up in bottom up way, staff members are defining their own objectives and based on their objectives managers are defining their own objectives. Another issue is with measurement of performance, and that with staff and financial performance, in practice managers will evaluate with high scores their staff in order to have better performance for their units.

\section{Compensation Philosophy}

Stewart (2000) discusses that actual philosophy of compensation has to do with competitive levels of compensation, performance related pay and significant levels of pay at risk. However, according Werner, Tosi, and Mejia, (2005) it is in executives and top managers' autonomy to decide for bonus payments and since there are not any constrains from shareholders, they are falling in temptation to link the payment criteria with results that they can control. This is leading to the conclusion that there are gaps between shareholder s' interests and managers' interests. Chief Executive Officers (CEO) and managers are acting on behalf of shareholders and their duty is to protect interests and to make profit for shareholders and they are core values for any company, and they are working in exchange for the payment. 
Werner (1995), states, “There is empirical evidence that a firm's ownership structure is reflected in the way top managers are paid, since compensation strategy is one way to align the incentives of principals and agents" (p.1674)

Science of organizational behavior is offering lot of motivation theories like Maslow need hierarchy theory, Herzberg's two-factor theory and Alderfer's ERG theory. One of the problems during the implementation of theories by managers is fact that employees already now those theories and according to Schonburg and Stern, (1999), nowadays most of the employees possess leadership, managerial and interpersonal skills.

Some companies are using bonus payments and penalties, depending on success or on failure regarding performance of their staff. Regarding this method Werner and Tosi and Mejia, 2005, states that "incentive-based compensation schemes for employees may increase performance, yet they may reduce employee satisfaction" (p.379). Based on author personal experience it is known that penalties are not serving as motivating factor, when author was employed by Mercedes Benz as General Manager (for Kosovo) he used to punish his staff for every mistake with salary deduction of $20 €$ (their salary was $600 €)$, but instead of improved performance, his staff had started to praise themselves.

So what companies should do in order to 'convince' their staff to perform well and take care about shareholders capital? As an option could be bonus payment, which is related to their performance, but at the end of the day employees will get used to receive bonus payment and at the moment when they will not receive bonus payment, they will be demotivated. Another option could be to give some stock and to relate employee's benefits with company profit, but Stewart (2000) had identified four important limitations, and those limitations are: volatility, market mystery, non-operating and, line of sight. In a case that employess with have stock option, they will become shareholdres and by default they will have decission making power. The problems can arrise in a case when company need to invest and to take a portion of risk, since most of employess will not be ready to take risks since they will prefer stability. If company will issue stock option to employess then in company board will bring people which have lack of global market knolwledge.

\section{High Powered Stock Options}

Option grant guidelines and exercise price mechanics are implemented as models for employee benefits, but they can undermine compensation objectives. Ownership guidelines creates connection between payments and performance and it seems they are functioning as a solution for payment for senior level and this is just one part of solution, since in lower levels "equity incentives tend to become less effective and risk only marginal benefits at substantial economic cost" (Stewar, 2000, p.5).

In a new economy, as a compensation solution companies should implement approach of fixed share grant, instead of fixed value grant. With this step employees would be more motivated and they would be more concern abot the value of company, and as a result their performance will be at a higher level. In order to keep high level of motivation, companies could implemnet long term plans which should have in package bonus paymnets.

Despite huge experience and knowledge, companies are making mistakes during the process of measurmment of performance. Stewart (2005) has identified two common mistakes that companies are conducting, the first mistake has to do with the case where companies are adding more and layering new measures, which leave participants on their one to find solution for problems and to identify real goals. While the second identified mistake has to do with confusion between expectations and desires and the bonuses warranted for each.

Regarding compensation there is a difference between publicly owned companies and private companies, for example in company where author is employed (Post and Telecom of Kosovo, publicly owned company), each employee is entilted to receive bonus payment, and bonus is received twice in year. This payment is not serving as a motivating factor and does not have any impact on performance, 
since everybody know that they will receive bonus payment, regardless their perfomnace. While when author wass employed by a private company, his bonus was 10 percent of the profit.

\section{Changes in Compensation}

Actual compensation design is influenced by characteristics that make this design dysfunctional, and those characteristics according to Stewart (2005) are too many measurers, performance legacy issues, "budget arbitration", big baths/performance ceilings, and short term and fractionated. Those characteristics are jeopardizing the main goal of payment to performance, and often they are initiating sub-optimal behaviors.

In order to avoid and to minimize impact of those characteristics, adoption of new approach for compensation is needed and this approach should create owner-employee contract to share value creation. Therefore, there is a need for entirely new design of payment policies and benefits and not just better performance measure. As identified measure by Stewart (2000) is "A Better, Single Measure. Economic value added (EVA) simply and simultaneously captures profit, capital and the cost of capital, converting net present value into a flow measure. EVA improvement, or growth, as the strategic imperative directs resources to their most productive uses - the maximization of shareowner wealth." (p.7). In addition, companies should implement also value-based goal-setting, multi-year accountability and equity-like payoff. All those measures will have positive impact, they will make staff into business leaders who think, act, and are paid like, owners.

\section{Conclusions}

Employees are creating profit for shareholders and for companies in exchange for a salary, their performance is measured by managers and employee are getting promoted and they are receiving extra payment based on their results. Performance can be defined as a sum of motivation and ability to perform. Regarding motivation literature is proving different theories, but the issue is that employees nowadays are more informed and have greater expectation from companies regarding compensation.

Since 15th century, businesses are using the same performance measuring system and reward schemes. In many companies, it is in executives and top manager's autonomy to decide for bonus payments, and since there are not any constrains from shareholders, they are falling in temptation to link the payment criteria with results that they can control. While in other cases companies are using rewards for good performance and penalties for not accomplished goals, but in a long term penalties are becoming demotivating factor.

Companies should find the way to push employees and their managers to think and to act as shareholders, this can be done with stock options, but most of employees are not ready to undertake risks that are related with stock market and they may hesitate to invest in products that may be associated with a risk.

An ownership guideline creates connection between payments and performance and it seems they are functioning as a solution for payment for senior level.

In a new economy, as a compensation solution companies should implement approach of fixed share grant, instead of fixed value grant. With this step employees would be more motivated and they would be more concern abot the value of company. But many companies are making mistakes during the process of measurmment of performance like adding more and layering new measures and creating confusion between expectations and desires and the bonuses warranted for each.

Actual compensation design is influenced by characteristics that make this design dysfunctional and in order to avoid and to minimize impact of those characteristics, adoption of new approach for 
compensation is needed and this approach should create owner-employee contract to share value creation. As the proposed solution is implementation of EVA, value-based goal-setting, multi-year accountability and equity-like payoff.

In the end of the day goal of shareholders, executive should be to convince their employees to think and to act as a shareholders, and to make them aware that their salaries and bonuses are related with value of company and with shareholders capital.

\section{References}

1 Schonburg, J., \& Stern, E. (1999, June). The capitalist manifesto the transformation of the corporation employee captalism. EVAluation, 1(4), pp. 1-17.

2 Stewart, G. B. (2002, September). Accounting is broken here's how to fix it a radical manifesto. Stern Stewart, 5(1), pp. 1-29.

3 Stewart, S. (2000). Compensation strategyfor the new economy age. EVAluation, 1-10.

4 Werner, S. (1995). Other people's money: the effects of ownership on compensation strategy and managerial. Academy of Management Journal, 38(6), 1672-1691.

5 Werner, S., Tosi, H. L., \& Mejia, L. G. (2005). Organizational governance and employee pay: how ownership structure affects the firm's compensation strategy. Strategic Management Journal, 26(4), 377384. 